\title{
Insuficiența cardiacă pediatrică
}

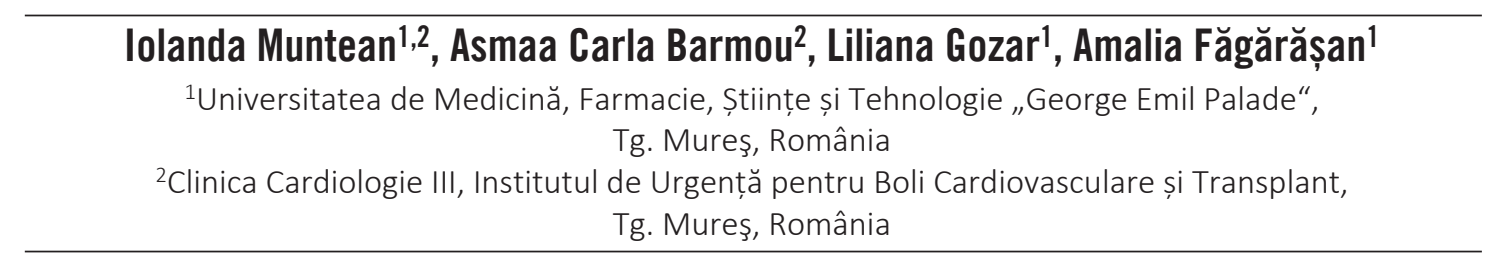

\section{REZUMAT}

Insuficiența cardiacă pediatrică reprezintă o provocare în practica clinică și o povară la nivel mondial. În comparație cu populația adultă, etiologia insuficienței cardiace la copii este dependentă de vârsta pacienților. Cu toate acestea, ghidurile referitoare la insuficiența cardiacă pediatrică sunt extrapolate din ghidurile pentru adulți. În cazul sugarilor și al copiilor, tratamentul farmacologic este bazat pe inhibitori de enzimă de conversie, betablocante, antagoniști ai receptorilor de aldosteron și alte diuretice (în prezența congestiei). În insuficiența cardiacă terminală, dispozitivele de asistare ventriculară sau diferite intervenții chirurgicale paliative sunt utilizate ca o punte pentru transplant sau recuperare.

Prezenta lucrare se concentrează pe cele mai importante cauze, mecanisme fiziopatologice, manifestări clinice și managementul în insuficiența cardiacă pediatrică, bazate pe cele mai recente ghiduri. În plus, subliniază cele mai noi tratamente farmacologice și nonfarmacologice recent aprobate pentru populația pediatrică

Cuvinte cheie: insuficiență cardiacă pediatrică, management clinic, tratament farmacologic, dispozitive de asistare ventriculară, transplant cardiac

\section{INTRODUCERE}

Insuficiența cardiacă (IC) pediatrică reprezintă o problemă semnificativă la nivel global, din cauza costurilor crescute cauzate de spitalizarea frecventă și prelungită [1]. Din cauza lipsei studiilor randomizate în populația pediatrică, prevalența reală a IC pediatrice este încă necunoscută $[2,3]$. De asemenea, ghidurile pentru IC pediatrică sunt bazate pe ghidurile de IC ale adultului sau pe opiniile experților, transformând managementul IC pediatrice într-o problemă semnificativă în practica clinică $[4,5]$. În acest context, acest articol trece în revistă cele mai importante probleme legate de etiologia, clasificarea și managementul IC în populația pediatrică.

\section{DEFINIȚIE ŞI ETIOLOGIE}

Potrivit ghidurilor Societăţii Internaţionale de Transplant Cardiac şi Pulmonar (ISHLT), IC este definită ca „un sindrom clinic și fiziopatologic apărut din cauza disfuncției ventriculare și/sau ca urmare a supraîncărcării de volum sau presiune“ " [4]. În acest context, etiologia IC la copil este împărțită în două grupuri mari: cardiomiopatiile (CMP) pe de-o parte, care determină în principal disfuncție ventriculară pe cord structural normal, și bolile cardiace congenitale (BCC), pe de altă parte, care se asociază cu supraîncărcarea de volum și /sau presiune [6]. De asemenea, etiologia IC este dependentă de vârstă. CMP sunt principala cauză de IC în cazul copiilor mari. În momentul diagnosticului CMP, rata de incidență a IC diferită în funcție de tipul CMP: 70\% dintre pacienții cu cardiomiopatia dilatativă (CMD) prezintă semne de IC, spre deosebire de doar $13 \%$ dintre cei cu cardiomiopatie hipertrofică $(\mathrm{CMH})$ [7]. BCC reprezintă principala cauză de IC în cazul nou-născuților și a sugarilor. Deși, în ultimii ani, diagnosticul precoce și intervențiile chirurgicale paliative și corective au dus la creșterea ratei de supraviețuire a acestor pacienți, pe termen lung, aceștia pot dezvolta complicații, care vor duce la apariția IC $[8,9]$. De asemenea, etiologia 
IC diferă și în funcție de poziția geografică: în țările în curs de dezvoltare, anemia secundară malnutriției sau malaria reprezintă cauze importante de IC $[10,11]$.

\section{STADIALIZAREA IC}

Managementul optim al IC a impus stadializarea IC. Există mai multe scale bazate pe semnele și simptomele clinice: scala NYHA (New York Heart Association) sau ROSS (tabelul 1). Scala NYHA este limitată în cazul pacienților sub 6 ani, pentru aceștia fiind creată scala ROSS. Ambele clasificări pot fi utilizate pentru a caracteriza severitatea IC, însă niciuna nu descrie stadiul inițial de boală și progresia acesteia [4]. Astfel, Societatea de Cardiologie Americană (AHA), în colaborare cu ISHLT, a elaborat un nou sistem de clasificare pentru IC la adult, extrapolat și în populația pediatrică [12].

\section{FIZIOPATOLOGIE}

Cunoașterea mecanismelor fiziopatologice implicate în IC este esențială, cunoscut fiind faptul că în ultimii ani tratamentul farmacologic al IC vizează în special căile patogenetice implicate, consecințele lor fiziopatologice precum și stimularea mecanismelor reparatorii endogene.

Astfel, din punct de vedere fiziopatologic, conform Schrantz și colab., debitul cardiac este determinat de: presarcină (volumul sanguin), postsarcină (rezistența vasculară), frecvența cardiacă, contractilitatea miocardică, dar și de sincronismul ventricular și interacțiunea ventriculo-ventriculară [13]. Astfel, scăderea debitului cardiac poate fi consecința afectării unuia sau mai multor factori.

Ca răspuns la scăderea debitului cardiac, sunt activate o serie de mecanisme neuroendocrine. În primul rând, stimularea sistemului nervos simpatic (SNS) va duce la activarea catecolaminelor, care vor determina inițial tahicardie, creșterea contractilității și vasoconstricție. De asemenea, stimularea SNS va crește secreția de hormon antidiuretic (ADH), ce determină resorbția de apă la nivel renal. În al doilea rând, se produce activarea sistemului renină-angiotensină-aldosteron (SRAA). Angiotensina II este un vasoconstrictor care contribuie la remodelarea cardiacă și supraîncărcarea de volum, iar aldosteronul stimulează retenția de apă și de sodiu la nivel renal [14]. Astfel, activarea mecanismelor compensatorii pot restabili pentru o perioadă de timp un echilibru cardiovascular. Pe termen lung, aceste mecanisme devin maladaptative, ducând la apoptoza cardiomiocitelor, creșterea fibrozei, remodelarea cardiacă și progresia IC [5].

Pe de altă parte, există în organism o serie de peptide (ex. atrial natriuretic peptide ANP, brain natriuretic peptide BNP), care pot contracara efectele nefavorabile determinate de SNS şi SRAA, prin: vasodilatație, stimularea natriurezei și a diurezei. Dar aceste peptide sunt distruse de către o enzimă numită neprilizină, secretată în exces în IC cronică [6].

\section{TERAPIA FARMACOLOGICĂ A IC}

În practica pediatrică, în momentul de față, tratamentul farmacologic al IC constă în modularea a

TABEL 1. Clasificarea NYHA/ROSS/ISHLT [4,14]

\begin{tabular}{|c|c|c|c|c|c|}
\hline & Fără IC & I & II & III & IV \\
\hline NYHA & - & Asimptomatici & $\begin{array}{l}\text { Simptome la activitate } \\
\text { fizică ușoară/moderată }\end{array}$ & $\begin{array}{l}\text { Simptome la activitate } \\
\text { fizică marcată }\end{array}$ & $\begin{array}{l}\text { Apariția simptomelor în } \\
\text { repaus }\end{array}$ \\
\hline ROSS & - & Asimptomatici & $\begin{array}{l}\text { Tahipnee ușoară sau } \\
\text { diaforeză în timpul } \\
\text { alimentației - în cazul } \\
\text { nou-născuților/sugarilor } \\
\text { Dispnee - în cazul } \\
\text { copiilor mai mari } \\
\end{array}$ & \begin{tabular}{|l} 
Tahipnee marcată sau \\
diaforeză în timpul \\
alimentației- în cazul \\
nou-născuților/sugarilor \\
Dispnee accentuată - în \\
cazul copiilor mai mari \\
\end{tabular} & $\begin{array}{l}\text { Tahipnee, tiraj, geamăt, } \\
\text { diaforeză- în repaus }\end{array}$ \\
\hline $\begin{array}{l}\text { ISHLT } \\
\text { stadiu }\end{array}$ & $\begin{array}{l}\text { A } \\
\text { Pacienți cu risc } \\
\text { de a dezvolta } \\
\text { în viitor IC, cu } \\
\text { funcție cardiacă } \\
\text { și dimensiuni } \\
\text { ale cavităților } \\
\text { cardiace- normale }\end{array}$ & \begin{tabular}{|l} 
B \\
Pacienți cu \\
anomalii de \\
structură și/ \\
sau funcție \\
cardiacă, însă \\
fără simptome \\
caracteristice \\
de IC
\end{tabular} & \multicolumn{2}{|c|}{$\begin{array}{l}\text { C } \\
\text { Pacienți din stadiul B cu simptome caracteristice de } \\
\text { IC (actuale sau anterioare) }\end{array}$} & $\begin{array}{l}\text { D } \\
\text { Pacienți cu IC în ultimul } \\
\text { stadiu, care necesită } \\
\text { terapie continuă cu } \\
\text { agenți inotropici sau } \\
\text { prostaglandină în vederea } \\
\text { menținerii patenței } \\
\text { ductului arterial, suport } \\
\text { mecanic ventilator și/ } \\
\text { sau suport circulator, } \\
\text { transplant cardiac }\end{array}$ \\
\hline
\end{tabular}


patru căi fiziopatologice: angiotensina II, catecolamine (norepinefrina), aldosteronul și neprilizina.

Pentru a acționa pe angiotensina II, avem la dispoziţie inhibitorii de enzimă de conversie (IECA) și blocanții receptorilor de angiotensină. Cei mai utilizați reprezentanți ai inhibitorilor de enzimă de conversie sunt Captopril și Enalapril [15]. În prezent, studiile se concentrează pe o nouă generație de IECA tisulari, precum Lisinopril. Inhibitorii de enzimă de conversie tisulari au anumite avantaje faţă de IECA serici: în primul rând, complianța la tratament este mai bună datorită unei singure administrări pe zi; în al doilea rând, aceștia determină efecte benefice de remodelare a țesuturilor vasculare și miocardice $[16,17]$. În cazul pacienților cu BCC și disfuncție ventriculară stângă, IECA sunt recomandați doar în situații particulare (ex. regurgitări valvulare) [4].

Blocanții receptorilor de angiotensină (ARB) sunt recomandați de către ISHLT în cazul pacienților care nu tolerează terapia cu IECA. Cel mai utilizați reprezentanţi sunt Valsartan și Losartan [4].

Studiile recente s-au concentrat pe o nouă metodă de a bloca SRAA. Combinația farmacologică dintre Sacubitril (inhibitor de neprilizină) și Valsartan (ARB) a fost recent aprobată de catre FDA pentru tratamentul IC la copiii peste 1 an simptomatici. Sacubitril scade concentrația endopeptidazei neprilizină, astfel inhibă degradarea peptidelor natriuretice (ANP, BNP) și determină vasodilatație, iar Valsartan inhibă angiotensina II, inhibând astfel vasoconstricția. În cazul pacienților sub 1 an, studiile sunt încă în desfășurare [16].

Pentru a acționa asupra SNS și a catecolaminelor în general, se utilizează betablocantele. Efectul benefic al acestora a fost demonstrat de o serie de studii [16]. Propranololul a fost primul betablocant utilizat în practica pediatrică, însă Carvedilol este cel mai prescris. În literatura de specialitate, există rezultate contradictorii legate de Carvedilol. Astfel, unele studii de mici dimensiuni au demonstrat efectele benefice ale terapiei cu Carvedilol asupra simptomatologiei şi a fracției de ejecție (FEj), spre deosebire de un studiu multicentric randomizat, care nu a decelat efecte semnificative în statusul clinic al pacienților după 8 luni de terapie $[18,19]$. În prezent, datorită efectului cardioprotectiv al stimulării receptorilor beta-2 (benefic în contextul fenomenului de downregulation la nivelul receptorilor beta-2, demonstrat în cazul pacienților cu CMD și IC), tot mai mulți clinicieni optează pentru prescrierea betablocantelor înalt selective pentru receptorii beta-1, și anume Bisoprolol $[13,20,21]$. Administrarea lui o dată pe zi crește complianța la tratament.

În cazul pacienților cu IC în stadiul C, betablocantele se asociază cu IECA și antagonişti ai receptorilor de aldosteron [12]. Însă utilitatea betablocantelor nu a fost dovedită în BCC cu fiziologie de ventricul unic [22].

Controlul frecvenței cardiace este esențial în tratamentul IC, având rolul de a îmbunătăți raportul dintre consumul de $\mathrm{O} 2$ miocardic și aport, precum și de a prelungi diastola [13]. Alături de betablocante, există și alte metode de a controla frecvența cardiacă la pacienții cu IC: Digoxin, Ivabradina. Digoxin poate fi utilizat pentru ameliorarea simptomatologiei în cazul pacienților cu FEj scăzută, alături de betablocante, IECA și antagonişti ai receptorilor de aldosteron [4]. În schimb, nu este indicat la pacienții cu FEj păstrată. Utilizarea lui a scăzut din cauza toxicității crescute și a interacțiunilor medicamentoase [19]. Ivabradina, un agent pur bradicardizant, este un blocant selectiv al curentului de pacemaker $\mathrm{I}_{\mathrm{f}}$, cu puține efecte adverse. A fost recent aprobat de FDA pentru pacienții cu IC simptomatici clasa II-IV NYHA/ROSS stabili, cu vârsta de peste 6 luni $[16,23]$.

Pentru a actiona asupra aldosteronului, se utilizează antagoniştii receptorilor de aldosteron. Deși diuretice mai slabe, au proprietăţi antifibrotice [4]. În cazul pacienților cu IC diastolică, utilizarea acestora nu este recomandată [4]. Cel mai utilizat antagonist al receptorilor de aldosteron este Spironolactona, fiind asociat cu inhibitori de enzimă de conversie (IECA) sau betablocante în cazul pacienților în stadiul C [24].

În cazul pacienților cu congestie pulmonară sau sistemică, pentru a controla simptomele și a reduce retenția lichidiană, de primă intenție sunt utilizate diureticele de ansă, cel mai prescris fiind Furosemid $[4,25]$. Studii recente s-au concentrat asupra unui nou agent diuretic, Tolvaptan, un antagonist al receptorilor vasopresinei-V2, care poate fi administrat ca un diuretic adițional în cazul pacienților pediatrici cu IC. Datorită proprietăților acestuia, Tolvaptan reduce congestia lichidiană prin creșterea volumului urinar și normalizarea concentrației de sodiu seric la pacienții cu hiponatremie [21].

Conform ghidurilor actuale, la pacientul cu IC în stadiul NYHA/ROSS II, se introduce progresiv tripla asociere medicamentoasă: betablocant - IECA - antagonist de receptori de aldosteron, ideal sub forma Bisoprolol-Lisinopril-Spironolactonă, cu tratament diuretic asociat, în funcție de existența semnelor de congestie $[4,13,26]$. De remarcat este faptul că, la ora actuală, majoritatea ghidurilor de IC pediatrică recomandă utilizarea tratamentelor farmacologice bazate pe nivelul de evidență C [6,20].

\section{TRATAMENTUL NONFARMACOLOGIC ÎN INSUFICIENȚA CARDIACĂ AVANSATĂ}

Odată cu agravarea stadiului NYHA/ROSS, în stadiul IV, pacienții necesită internare, cu introduce- 
rea inodilatatoarelor intravenoase. Cazurile refractare necesită tratament avansat. Terapia cu dispozitive și diversele intervenții chirurgicale paliative sunt utilizate tot mai des ca o punte pentru transplant sau recuperare.

Terapia cu dispozitive câștigă teren în tratamentul IC pediatrice în ultima perioadă. Implantarea de pacemaker este recomandată pentru pacienții cu bloc atrio-ventricular grad II/III asociat cu disfuncție ventriculară [4]. Implantarea de cardio-defibrilator (ICD) este recomandată supraviețuitorilor unui stop cardiorespirator [4]. Totuşi, a fost asociată cu o performanță suboptimală, aproximativ $25-40 \%$ dintre pacienți raportând șocuri ineficiente [27]. Terapia de resincronizare (CRT) este indicată în cazul pacienților din clasa funcțională NYHA II-IV, cu disfuncție ventriculară stângă, cu FEj sub 35\% și durata complexului QRS peste valorile normale pentru vârstă, asociate cu bloc de ramură stângă (clasa IIa, nivel de evidență B) sau bloc de ramură dreptă (clasa IIb, nivel de evidență C) [4]. Unele studii descriu îmbunătăţirea FEj şi a clasei funcționale NYHA, cu complicații similare între populația adultă și cea pediatrică [28].

\section{Suportul circulator mecanic şi transplantul cardiac}

Pe termen lung, TxC rămâne singura opțiune terapeutică pentru pacienții cu IC terminală, refractară la tratament. Dispozitivele de asistare ventriculară

\section{BIBLIOGRAFIE}

1. Nakano SJ, Miyamoto SD, Price JF, Rossano JW, Cabrera AG. Pediatric Heart Failure: An evolving public health concern. J Pediatr. 2020 Mar;218:217-221.

2. Ponikowski P, Voors A, Anker SD, et al.; Authors/Task Force Members; Document Reviewers. 2016 ESC Guidelines for the diagnosis and treatment of acute and chronic heart failure: The Task Force for the diagnosis and treatment of acute and chronic heart failure of the European Society of Cardiology (ESC). Developed with the special contribution of the Heart Failure Association (HFA) of the ESC. Eur J Heart Fail. 2016 Aug;18(8):891-975.

3. Hsu DT, Pearson GD. Heart failure in children: Part I: History, etiology and pathophysiology. Circ Heart Fail. 2009 Jan;2(1):63-70.

4. Kirk R, Dipchand AL, Rosenthal DN, et al.; The International Society for Heart and Lung Transplantation guidelines for management of pediatric heart failure: Executive summary. J Heart Lung Transpl. 2014 Sep;33(9):888-909.

5. Anderson R et al. Chronic cardiac failure: physiology and treatment. In: Pediatric cardiology, 3rd edition. Edinburgh: Churchill Livingstone 2009;257-267.

6. Das BB. Current state of pediatric heart failure. Children (Basel). 2018 Jun 28;5(7):88-98.

7. Wilkinson JD, Landy DC, Colan SD, et al. The pediatric cardiomyopathy registry and heart failure: Key results from the first 15 years. Heart Fail Clin. 2010 Oct;6(4):401-413.

8. Nandi D, Rossano JW. Epidemiology and cost of heart failure in children. Cardiol Young. 2015 Dec;25:1460-1468.

9. James N, Smith M. Treatment of heart failure in children. Current Paediatrics. 2005 Dec;15(7):539-548.
(VAD) și intervențiile chirurgicale paliative sunt utilizate ca o punte pentru recuperare sau TxC [29]. Registrul Inter-Agenţii a Suportului circulator asistat mecanic (INTERMACS) a dezvoltat 7 profiluri clinice pentru a avea o selecție mai potrivită a pacienților cu IC în ultimul stadiu și a terapiilor corespunzătoare [30]. Implantarea unui VAD este recomandată în caz de IC terminală asociată cu cel puțin o insuficiență de organ (clasă I, nivel de evidență C) [4].

În cazul pacienților cu CMD, Schrantz și colab. au propus banding-ul reversibil de arteră pulmonară ca intervenție chirurgicală paliativă inovatoare, recomandată copiilor $<6$ ani cu IC ROSS/NYHA clasa III/IV, cu FEj scăzută și funcția VD păstrată [31]. Banding-ul de arteră pulmonară s-a dovedit a avea în timp efecte benefice asupra funcției și mărimii VS, a FEj, însă mortalitatea este încă necunoscută, iar eficacitatea este demonstrată doar în cazul sugarilor sau al copiilor mici.

\section{CONCLUZII}

Insuficiența cardiacă pediatrică este un sindrom complex, cu multiple etiologii şi cu mortalitate și morbiditate semnificative. În ciuda progreselor tehnologice, IC pediatrică rămâne o provocare pentru clinicieni. Studiile viitoare ar trebui să se concentreze asupra terapiei farmacologice personalizate, bazată pe mecanismul fiziopatologic implicat, procesele moleculare și etiologia IC.

10. Masarone D, Valente F, Rubino M, Vastarella R, Gravino R, Rea A, Russo MG, Pacileo G, Limongelli G. Pediatric Heart Failure: A Practical Guide to Diagnosis and Management. Pediatr Neonatol. 2017 Aug;58(4):303-312.

11. Madriagao $E$, Silberbach $M$. Heart failure in infants and children. Pediatr Rev. 2010 Jan;31(1):4-12.

12. Stout KK, Broberg CS, Book WM, Cecchin F, Chen JM, Dimopoulos K, Everitt MD, Gatzoulis M, Harris L, et al.; American Heart Association Council on Clinical Cardiology, Council on Functional Genomics and Translational Biology, and Council on Cardiovascular Radiology and Imaging. Chronic Heart Failure in Congenital Heart Disease: A Scientific Statement From the American Heart Association. Circulation. 2016 Feb 23;133(8):770-801.

13. Schrantz D, Voelkel NF. "Nihilism" of chronic heart failure therapy in children and why effective therapy is withheld. Eur J Pediatr. 2016 Apr;175(4):445-455.

14. Knudson JD, Cabrera AG. The Pathophysiology of heart failure in children: The Basics. Curr Cardiol Rev. 2016;12(2):99-103.

15. Diez CC, Khalil F, Schwender H. et al. Pharmacotherapeutic management of paediatric heart failure and ACE-I use patterns: a European survey. BMJ Paediatrics Open. 2019 Jan;3(1):e000365.

16. Stidham J, Feingold B, Almond CS, Burstein DS, Krack P, Price JF, Schumacher KR, Spinner JA, Rosenthal DN, Lorts A, Godown J. Establishing Baseline Metrics of Heart Failure Medication Use in Children: A Collaborative Effort from the ACTION Network. Pediatr Cardiol. 2021 Feb;42(2):315-323.

17. Gisler F, Knirsch W, Harpes P, Bauersfeld U. Effectiveness of angiotensin-converting enzyme inhibitors in pediatric patients with 
mid to severe aortic valve regurgitation. Pediatr Cardiol. 2008 Sep;29(5):906-9.

18. Rusconi P, Gomez-Marin O, Rossique-Gonzalez M, et al. Carvedilol in children with cardiomyopathy: 3-year experience at a single institution. J Heart Lung Transplant. 2004 Jul;23(7):832-838.

19. Shaddy RE, Boucek MM, Hsu D, et al. Carvedilol for children and adolescents with heart failure: A randomized controlled trial. JAMA. 2007 Sep;298(10):1171-1179.

20. Recla S, Schmidt D, Logeswaran T, Esmaeili A, Schranz D. Pediatric heart failure therapy: why $\beta 1$-receptor blocker, tissue ACE-I and mineralocorticoid-receptor-blocker?. Transl Pediatr. 2019 Apr; 8(2):127-132.

21. Li B, Fang D, Qian C, Feng H, Wang Y. The efficacy and safety of Tolvaptan in patients with hyponatremia: a meta-analysis of randomized controlled trials. Clin Drug Investig. 2017 Apr; 37(4):327-342.

22. Garcia AM, Beatty JT, Nakano JS. Heart failure in single right ventricle congenital heart disease: Physiologic and molecular considerations. Am J Physiol Heart Circ Physiol. 2020 Apr;318(4):H497-H965.

23. Bonnet $\mathrm{D}$, Berger $\mathrm{F}$, Jokinen $\mathrm{E}$, et al. Ivabradine in Children With Dilated Cardiomyopathy and Symptomatic Chronic Heart Failure. J Am Coll Cardiol. 2017 Sep;70(10):1262-1272.

24. Rossano JW, Shaddy RE. Heart failure in children: Etiology and treatment. J Pediatr. 2014 Aug;165(2):228-233.

25. Macicek SM, Macias CG, Jefferies JL, et al. Acute heart failure syndromes in the pediatric emergency department. Pediatrics. 2009 Nov;124(5):e898-904.

\section{Conflict of interest: none declared}

Financial support: none declared
26. Kantor PF, Lougheed J, Dancea A et al.; Children's Heart Failure Study Group. Presentation, diagnosis and medical management of heart failure in children: Canadian Cardiovascular Society Guidelines. Can J Cardiol. 2013 Dec;29(12):1535-1552.

27. Atallah J, Erickson C, Cecchin F, et al.; Pediatric and Congenital Electrophysiology Society (PACES). Multi-Institutional study of implantable defibrillator lead performance in children and young adults. Results of the pediatric lead extractability and survival evaluation (PLEASE) study. Circulation. 2013 Jun; 127(24):2393-2402.

28. Janousek J, Gebauer RA, Abdul-Khaliq H, et al. Working Group for Cardiac Dysrhythmias and Electrophysiology of the Association for European Paediatric Cardiology. Cardiac resynchronisation therapy in paediatric and congenital heart disease: differential effects in various anatomical and functional substrates. Heart. $2009 \mathrm{Jul}$; 95(14):1165-1171.

29. Dodd DA. Pediatric heart failure and transplantation: Where are we in 2013?. Curr Opin Pediatr. 2013 Oct; 25(5):553-560.

30. Stevenson LW, Pagani F, Young JB. INTERMACS profile of advanced heart failure: the current picture. J Heart Lung Transplant. 2009 Jun; 28(6):535-541.

31. Schrantz D, Recla S, Malcic I, et al. Pulmonary artery banding in dilative cardiomyopathy of young children: review and protocol based on the current knowledge. Transl Pediatr. 2019 Apr; 8(2):151-160. 